\title{
THE AUSTRO-HUNGARIAN COMPROMISE OF 1867 AND ITS CONTEMPORARY CRITICS
}

\author{
TIBOR FRANK \\ Eötvös Loránd University, Budapest, \\ Hungary
}

Though the revolutions of 1848-1849 were ultimately put down by the Habsburgs and their Russian allies, Austria came out of this Pyrrhic victory as a much weakened power.

A series of international conflicts such as the Italian wars of 1859 and 1866 and, particularly, the Prussian war of 1866 clearly demonstrated that Austria was no longer the major military power that it had been during the long decades when Prince Metternich's Holy Alliance system was at work. The international status of the empire was increasingly dependent upon its unavoidable internal, structural reorganization which was destined to recreate the economic and social energies of this vast East-Central European realm. The Austro-Hungarian Compromise was the last, and perhaps the most fundamental reorganization of the Habsburg Empire before it went down in history after World War I.

As Hungary had been part of that Empire since 1526, the Compromise reshaped the constitutional status and political standing of Hungary in a major way. From a pseudo-colonial province the country invented itself as a semi-autonomous part of the Habsburg Empire which was reconstituted as the dualist structure of the Austro-Hungarian Monarchy. In many ways, this transformation was made possible by the revolution and war of independence of 1848-1849 which, among other results, helped reshape the international position and image of Hungary. ${ }^{1}$

What were the essential features of the dualist Monarchy? To what extent was it indeed based on the principle of "dualism" and how much did it retain from the absolutist legacy of the Habsburg Empire? The debate about these questions is almost older than the newly established system itself, as discussions were started right during the formative years of the Dual Monarchy.

Theoretically, the Monarchy became divided into two legally equal parts with their relations based on parity. The two parts were internally sovereign, with their own legislative, legal, and law enforcing mechanisms. It was the common monarch who regulated their relationship at the topmost level, while the three most important "common" affairs were managed jointly. ${ }^{2}$ Some of these "common" affairs such as foreign policy, defense and finances related to those two were de- 
duced from the Pragmatica Sanctio of the Emperor Charles III in the early 18th century. ${ }^{3}$

The highest (and perhaps best documented) executive body of the dual monarchy was the Common Council of Ministers. If presided over by the monarch, it was called the Crown Council. Out of the "joint" ministers, the role of the minister for foreign affairs was particularly crucial: not only was he responsible for foreign affairs, but he was a leading policy maker for the whole empire, in terms of the basic political guidelines. The dual Monarchy had two parliaments which never met but communicated through the institution of the "delegations" only. They were designed to guarantee the constitutionality of foreign and military affairs. Soon, however, they turned out to be unfit for fulfilling their parliamentary functions, and thus helped maintain some of the unconstitutional powers of the monarch. The common ministries were also allowed to function essentially without constitutional control. Foreign affairs, however, were influenced by "the ministries of both halves," including of course the Hungarian government and parliament. ${ }^{4}$

After the unification of Buda, Pest, and Old-Buda into one municipality in 1873, the newly constituted Monarchy had two capital cities: Vienna and Budapest. While Vienna was the old imperial capital city of the Habsburgs, Budapest emerged astonishingly quickly, basically by the end of the 19th century, as a beautiful, modern city to serve as the administrative and economic center of the Hungarian part of the Monarchy. In some ways it was designed to impress the many different ethnic minorities of the country by the visible ability of the Magyar ruling élite to govern their land. Overlooking the Danube across the Royal Palace, the building of Parliament dominated the landscape as a symbol of constitutionalism and political power.

Considering its legal status and structure, the newly established Monarchy was different from all the major powers of Europe. It differed from the centralized model of the French or the Russians, but it was also different from the Swiss model that recognized the equal rights of the constituent elements, or from the German model built on the preponderance of the Prussian element. To some extent it showed some resemblance to the Swedish-Norwegian arrangement of 1814 though it had particular qualities that made it special. ${ }^{5}$

Despite the obvious and major changes in 1867, the Austro-Hungarian Monarchy became a curious mixture of constitutionalism and absolutism. The personal power of the monarch remained very strong throughout the life of Emperor-King Francis Joseph I (1830-1916) who maintained his personal influence in his increasingly constitutional monarchy. The chief adversary of the system, the revolutionary leader of 1848-49 Lajos Kossuth (1802-1894) spent much of his long exile harshly criticizing the unconstitutional elements of the new arrangement. 
There is no dualism here, dreadfully no dualism. But there is a common Austro-Hungarian ministry; is this dualism?

There are common ambassadors, diplomatic representatives, even common consuls; is that dualism?

There is an Austrian and a Hungarian delegation, which [together] are more united a body than the two houses of the Hungarian Parliament because those do not vote together while the Austrian and Hungarian delegations do so; is that dualism?

Who decide the military budget, this most serious item of the public purse, quite independently from the control of both the Hungarian as well as of the Austrian legislative bodies? The two delegations together! Is that dualism?

And if these two bodies that meet in two rooms but vote together ... can't come up with a majority vote...?

[Then] the unified ruler of the unified Österreich-Ungarn takes a decision, without asking the nations, without their participation, with absolute power; is this dualism? ${ }^{6}$

Apart from foreign affairs, for Kossuth it was particularly the right of preapproval, an imperial-royal prerogative kept for the Monarch as well as the unified German language of the army that suggested danger for the constitutional future of the Monarchy.

Kossuth made his criticism internationally known not only later as this document showed, but also in his open letter addressed to Ferenc Deák, chief architect of the Compromise of 1867, as early as May 22, 1867. Published in Magyar Újság, this much quoted Paris letter reminded Kossuth's former political friend and fellow minister in the revolutionary government of 1848 of the legacy of the revolution and warned the compromising statesman "not to drag the country to the point where it cannot be master of its own destiny." "7

Kossuth continued to shower his criticism on his former friend and political ally attacking the new laws of 1867 which for him

run against the state life conditions of Hungary, clash with the political tendencies to which our nation, in good and bad fortune had always and steadfastly adhered to for three centuries and a half, and to the loyalty to which our nation can thank its existence; counteract the age in which we live, its direction, the suggestions of the European trends; are so dangerous in their power and lack the motivation of need, of constraint, of the status of the Austrian House, or of the necessities of the simplest political arithmetic ... ${ }^{8}$

Deák answered Kossuth's open letter in the Pesti Napló of May 30. He stated that it was his conviction

that in our position it is better to make a peaceful settlement than to let our future depend on policies that are founded on vague promises, 
that would cause further delays and suffering, and that would probably depend on happenstance, on revolution and the dissolution of the empire, on foreign aid (for which our interests would certainly not be the main motive), or on new foreign alliances, the form, purposes and advantages of which cannot yet be known. I have also stated that the means I have proposed for settlement does not jeopardize our constitutional freedoms and, in many respects, is advantageous to the country. These statements of mine, which were never addressed to passions but rather to calm common sense, have always been made openly. ${ }^{9}$

Equally serious contemporary criticism came from Prague. Though Francis Joseph made some symbolic gestures to his Czech sovereigns, these proved to be far from enough to appease Czech nationalists. For the Czech the constitutional settlement which left them out of the new arrangement seemed to be directed against their own national interests. František Palacký, the most influential advocate of a federal reconstruction of the Habsburg Empire, deplored the hegemony of the Germans and Hungarians in a reconstituted Monarchy and declared:

The day dualism is proclaimed ... will also be the birthday of Panslavism in its least desirable form, and the godparents of the latter will be the parents of the former. What will follow every reader can divine for himself. We Slavs will look forward to that with sincere grief, but without fear. We existed before Austria; we shall still exist when it is gone. ${ }^{10}$

The Poles of Galicia also requested their full administrative, judicial, and educational autonomy which the Austro-Hungarian settlement refused to grant out of deference to Russian sensibilities. ${ }^{11}$

More compassion was shown towards the restructuring of the Monarchy outside the Habsburg realm. German Chancellor Otto von Bismarck repeatedly praised the idea in his conversations with illustrious visitors from the Monarchy. To the famous Hungarian author Mór Jókai he declared his views concerning the necessity of maintaining the Dual Monarchy. Only the German and the Hungarian element can govern, he said, they alone possess statesmanlike qualities and knowledge. It would be impossible to maintain the system of small nation-states in East-Central Europe. Vienna and Budapest have the mission to become the rich centers of Eastern civilization and commerce. This seemed to be the very essence of the Central European policy of Bismarck also in a broader sense. ${ }^{12}$ Almost a decade later Bismarck reiterated his views to Crownprince Rudolf von Habsburg and emphasized the importance of the Hungarian participation in the Monarchy. There alone can the Hungarians gain their security amidst the sea of Slavic peoples, he suggested. Bismarck explicitly attacked the oppositional stance of Kossuth 
when declaring to the Crownprince that in critical moments Hungarians demonstrate the overbearing "self-confidence of the hussar and the lawyer." 13

In Britain, the new political structure attracted great interest for its obvious implications for Ireland. The First Lord of the Treasury, W. E. Gladstone sounded most appreciative in the Government of Ireland debate of 1886. He was convinced by the very existence of two parliaments in the Monarchy. "In Austria and Hungary there is a complete duality of power," he argued on April 8, 1886.

\begin{abstract}
I will not enter upon the general condition of the Austrian Empire, or upon the other divisions or diversities which it includes, but I will take simply this case. At Vienna sits the Parliament of the Austrian Monarchy; at Budapesth sits the Parliament of the Hungarian Crown; and that is the state of things which was established, I think, nearly 20 years ago. I ask all those who hear me whether there is one among them who doubts? Whether or not the condition of Austria be at this moment, or be not, perfectly solid, secure, and harmonious, after the enormous difficulties she has had to confront, on account of the boundless diversity of race, whether or not that condition be perfectly normal in every minute particular, this at least, cannot be questioned, that it is a condition of solidity and of safety compared with the time when Hungary made war on her - war which she was unable to quell when she owed the cohesion of the body politic to the interference of Russian arms; or in the interval that followed, when there existed a perfect Legislative Union and a supreme Imperial Council sat in Vienna? ${ }^{14}$
\end{abstract}

British critics of the Compromise, however, seemed to echo Kossuth's stern warnings. Members of Parliament such as G. J. Goschen pointed out that "Austria-Hungary ... is bound together by the power of the Crown and by the authority of the three Common Ministers, who are responsible to no Parliament at all." ${ }^{15}$ As if to repeat Lajos Kossuth, Sir John Lubbock, MP quoted Sir Henry Elliot, British Ambassador to Vienna, who in a letter to The Times "had expressed far from favourable opinion as to the result [of the Austro-Hungarian Monarchy], and if it worked at all it was greatly due to the large powers possessed by the Emperor."16

Towards the end of the 19th century a new, radicalized generation of Irish nationalists fighting for their Ireland also praised the Austro-Hungarian arrangement of 1867 conceiving it as 'A Parallel for Ireland.' ${ }^{17}$ In an article for The United Irishman of January 2, 1904, Arthur Griffith went out to declare:

You may be old enough yourself to remember when Hungary fell and 'Freedom shrieked aloud' - when Kossuth was a fugitive, with the bloodhounds of Austria on his track, when the Austrian dragoon was the Law from Buda-Pesth to the Carpathians, when day after day Hungarian patriots were shot or hanged like dogs by the victori- 
ous soldiery of Francis Josef, when in fact 'Peace reigned in Warsaw', and men said - 'Hungary was'. Therefore, when you look around today and see Hungary freer and stronger and more prosperous than Austria, when you know that if Hungary declared herself a republic tomorrow - which she intends to do when the sad old man who reigns in Vienna dies - Austria would not fight, because she could not - you may well rub your eyes, reflecting that Hungary never once sent a Parliamentary Party to Vienna to 'fight on the floor of the House' for Home Rule, never once admitted the right of Austria to rule over her, never once pretended to be 'loyal' to the Power that had smitten her, never once held monster indignation meetings and resolutioned, and fired strong adjectives - and yet, notwithstanding, forced Austria to her knees and wrung from her unwilling hands the free Constitution which has made Hungary the Power she is to-day... ${ }^{18}$

Critics of Griffith observe that he misunderstood the nature of the AustroHungarian Compromise. In his Modern Ireland 1600-1972, Professor Roy Foster described "the Irish Ausgleich" as "the withdrawal of support for British institutions, from Parliament down. The corollary, that such a policy would have to be backed up by violence and intimidation, was ignored." 19 To boot, it was also pointed out more recently that "in the compromise of 1867 Hungary did not wrest freedom from Austria...[its] conservative-liberal elements, rather than its revolutionaries, struck a deal..."20

The official French response to the Compromise of 1867 was extremely positive. The French Ambassador to Vienna, the Duc de Gramont (whose devastating policies as French Foreign Minister in 1870 were to facilitate the outbreak of the Franco-Prussian War), suggested that the Hungarians need the other parts of Austria just as Austria needs the Hungarians, as they can only exist if combined in a major empire. He expressed his hope that constitutional developments will end the tensions among the individual parts of the realm. Responding to the Ambassador, French Foreign Minister Lionel Marquis de Moustier declared how important the consolidation of the Monarchy will be for the maintenance of the European equilibrium. ${ }^{21}$

Later commentators in France were much less enthusiastic for the Austro-Hungarian Compromise. French public opinion was divided: most people would have favored federalism, and even those who accepted the new structure intended to give the other ethnic groups of the Monarchy gradually more rights. French concern for the ethnic minorities of the Monarchy led to disillusionment in AustriaHungary and ultimately brought about an anti-Austro-Hungarian and anti-Hungarian French foreign policy with fatal consequences after World War I. ${ }^{22}$

The Austro-Hungarian Compromise made a tremendous impact on Central European history in the fifty years before World War I. It was remarkably well 
received by the European powers, but was rejected by the many ethnic groups inside the Monarchy. Its failure to create a stable and livable political system for the major ethnic groups of the Monarchy was not compensated by the economic and cultural success it produced. It started capitalist development in Hungary, for which it secured a semi-great-power status. It recognized the emancipation of the Jews, and helped create an aura of liberalism in the Monarchy. In many ways, however, it paved the way toward the one-sided Austro-Hungarian-German orientation and military alliance which directly contributed to the dissolution of the Monarchy and the tragic Peace Treaties of 1919-1920. It did not guarantee the same rights to the ethnic minorities that Hungarians and Germans were to enjoy themselves. It preserved the agricultural bias of Hungarian economy within an imperial division of labor. It created a capital city for Hungary which was overdeveloped vis-à-vis rural Hungary.

To this day, international historiography has made repeated efforts to comprehend the significance and legacy of the Compromise, without ever solving its major dilemma signaled already by the contemporaries: was it a success or a failure? The question often assumed political and even symbolic significance. In the last few decades some of the most important books on Hungarian history were in fact written on issues related to the Compromise and functioned like political arguments in an era, particularly after 1956, when opposition views had to be voiced through doublespeak..$^{23}$ Generations of modern Hungarian historians have been coping with the issue of the Compromise which became one of the central pivots of historical thought in Hungary. ${ }^{24}$

Contemporary criticism, as is so often the case, continues to survive in the form of historiographical arguments, sometimes highly charged by the heated aura of daily politics.

\section{Notes}

1. Most recently see the complete new overview by Domokos Kosáry, Magyarország és a nemzetközi politika 1848-1849-ben [Hungary and International Politics in 1848-1849] (Budapest: História - MTA Történettudományi Intézete, 1999).

2. Tibor Frank, "Hungary and the Dual Monarchy, 1867-1890," in: Peter F. Sugar, Péter Hanák, and Tibor Frank, eds., A History of Hungary (Bloomington and Indianapolis: Indiana University Press, 1994), 252.

3. Horst Haselsteiner, "Cooperation and Confrontation between Rulers and the Noble Estates, 17111790," in: Peter F. Sugar, Péter Hanák, and Tibor Frank, eds., A History of Hungary (Bloomington and Indianapolis: Indiana University Press, 1994), 143-145.

4. Tibor Frank, "Hungary and the Dual Monarchy, 1867-1890,", op. cit., 253.

5. István Diószegi, Bismarck és Andrássy. Magyarország a német hatalmi politikában a XIX. század második felében [Bismarck and Andrássy. Hungary in the German Power Politics of the Second Half of the 19th Century] (Budapest: Teleki László Alapítvány, 1998), 20. For the comparison 
with Sweden and Norway see the interesting comments of W. E. Gladstone in the 1886 Government of Ireland debate, April 8, 1886, House of Commons, Hansard's Parliamentary Debates, 1886, col. 1046-1047.

6. Lajos Kossuth, "A dualizmus értéke" [The Value of Dualism], First publ. in Irataim, Vol. V, repr. in Kossuth Lajos válogatott munkái [Select Works of Lajos Kossuth], ed. Ferencz Kossuth (Budapest: Franklin, n.d.), 366-367.

7. Lajos Kossuth, "Nyílt levél Deák Ferenczhez" [Open Letter to Ferencz Deák], Paris, May 22, 1867, in Kossuth Lajos válogatott munkái [Select Works of Lajos Kossuth], ed. Ferencz Kossuth (Budapest: Franklin, n.d.), 187.

8. Ibid.

9. Deák Ferenc beszédei [The Addresses of Ferenc Deák] (Budapest, 1903), Vol. V, 8-10. Quoted by Béla K. Király, Ferenc Deák (Boston: Twayne, 1975), 181-182.

10. Joseph F. Zacek, "Palacky and the Austro-Hungarian Compromise of 1867," in Anton Vantuch, ed., Der österreichisch-ungarische Ausgleich 1867: Materialien der internationalen Konferenz in Bratislava 28.8.-1.9.1967 (Bratislava, 1971). Quoted by Béla K. Király, Ferenc Deák (Boston: Twayne, 1975), 181.

11. Tibor Frank, "Hungary and the Dual Monarchy, 1867-1890,", op. cit., 254.

12. Otto von Bismarck, "Gespräch mit dem Dichter M. Jókai, Berlin, Februar 27, 1874," Otto von Bismarck, Die gesammelten Werke, Vol. 8, No. 74. Summarized by Imre Gonda, Bismarck és az 1867-es osztrák-magyar kiegyezés [Bismarck and the Austro-Hungarian Compromise of 1867] (Budapest: Akadémiai Kiadó, 1960), 162.

13. Otto von Bismarck, "Gespräch mit dem Kronprinzen Rudolf von Österreich, Februar 28, 1883. Based on Ludwig Ritter von Przibram. Otto von Bismarck, Die gesammelten Werke, Vol. 8, No. 346. Summarized by Imre Gonda, op. cit., 162-163.

14. William Ewart Gladstone in the Government of Ireland debate, April 8, 1886, House of Commons, Hansard's Parliamentary Debates, 1886, col. 1047.

15. George Joachim Goschen in the Government of Ireland debate, April 13, 1886, House of Commons, Hansard's Parliamentary Debates, 1886, col. 1465.

16. Sir John Lubbock in the Government of Ireland debate, April 9, 1886, House of Commons, Hansard's Parliamentary Debates, 1886, col. 1235.

17. Arthur Griffith, "The Resurrection of Hungary," The United Irishman, January 2, 1904. In: Arthur Mitchell and Pádraig Ó Snodaigh, eds, Irish Political Documents (Dublin: Irish Academic Press, 1989), 117.

18. Arthur Griffith, "The Resurrection of Hungary," op. cit.

19. Roy Foster, Modern Ireland 1600-1972 (London, 1988), 457.

20. Miklós Lojkó, "National Loyalties in the Peripheries of Europe," Proceedings of the John Hewitt Summer School, Belfast, 1995.

21. István Diószegi, op. cit., 24-25.

22. André Lorant, Le Compromis Austro-Hongrois et l'opinion publique française en 1867 (Genève: Droz, 1971), 67-149. (For a review in French see Tibor Frank, Annales Universitatis Scientiarum Budapestinensis de R. Eötvös Nominatae, Sectio Historica, 1977, 267-271.) For a European survey of how the various powers related to the Compromise see Endre Kovács, Ausztria útja az 1867-es kiegyezéshez [The Road of Austria to the Compromise of 1867] (Budapest: Kossuth, 1968), 210-331.

23. An excellent example was the magnum opus of György Szabad, Forradalom és kiegyezés válaszútján (1860-61) [On the Crossroads of Revolution and Compromise, 1860-61] (Budapest: Akadémiai Kiadó, 1967).

24. See Péter Hanák, "Historizálás és történetiség a kiegyezés vitájában" [Historicity and Historicality in the Debate on the Compromise] in Péter Hanák, Magyarország a Monarchiában [Hungary in the Monarchy] (Budapest: Gondolat, 1975), 159-221. 